\title{
Library Support for Student Financial Literacy: A Survey of Librarians at Large Academic Institutions
}

\section{Lauren Reiter and Bronson Ford*}

Financial literacy came to the forefront as the 2013-2014 presidential focus of the Association of College \& Research Libraries division of the American Library Association, bringing increased attention to the topic among academic librarians and encouraging an exploration into new and developing roles for academic libraries in financial education. Via a survey of academic librarians at large universities of more than 10,000 students, the authors seek to determine what types of financial literacy support academic libraries are providing, who is participating, what prompted the initiatives, and what are the main barriers, challenges, and opportunities.

\section{Introduction}

Managing debt and money have become a part of the college experience for many, as students face an increased expectation and need to take out loans to support their education. According to the Report on the Economic Well-Being of U.S. Households, 30 percent of adults borrowed to cover their own education-related costs in 2016, compared to 27 percent in both 2014 and 2015. ${ }^{1}$ Student Debt and the Class of 2016 determined student debt figures on a state-by-state basis, finding that average student debt of 2016 graduates ranged from a low of $\$ 19,975$ in Utah to a high of $\$ 36,367$ in New Hampshire. ${ }^{2}$ Relatedly, the Consumer Financial Protection Bureau found that the percentage of borrowers with student loan debt of $\$ 20,000$ or more has increased from 20 percent in 2002 to more than 40 percent as of August 2017, and the percentage of borrowers owing student loan debt of $\$ 50,000$ or more has increased from 5 percent to 16 percent during the same time period. ${ }^{3}$

College students have shown their willingness to take on debt alongside the other money challenges and financial decisions that often accompany the college experience, ranging from saving for a rental security deposit to applying for a credit card. The Study on Collegiate Financial Wellness 2017 Key Findings showed that, although the majority of students saw college as a valuable investment and maintained healthy financial behaviors such as tracking spending and planning for purchases, nearly 70 percent of students reported experiencing financial

*Lauren Reiter is Business Liaison Librarian at Pennsylvania State University; email: lmr29@psu.edu. Bronson Ford is Compliance Officer at Cantor Fitzgerald and a graduate of Pennsylvania State University; email: fordbronson@ gmail.com. The authors would like to express their gratitude and appreciation to Sally W. Kalin. This research was made possible by the Sally W. Kalin Early Career Librarianship for Learning Innovations. (C2019 Lauren Reiter and Bronson Ford, Attribution-NonCommercial (http://creativecommons.org/licenses/by-nc/4.0/) CC BY-NC. 
stress. ${ }^{4}$ Recent research has investigated the financial lives of millennials, a generation that includes many current college students and recent graduates. A 2015 research report supported by $\mathrm{PwC}_{\mathrm{W}} \mathrm{found}$ a number of concerning trends among millennials, including a lack of adequate financial knowledge, a lack of satisfaction with their financial situation, concerns about student loans, and a tendency not to seek out professional financial advice. ${ }^{5}$ An overview of the financial literacy of millennials worldwide showed that 57 percent of millennials in the United States are financially literate and drew attention to an increasing gap between the financial responsibilities given to this generation, such as retirement planning and higher education expenses, and their financial decision-making knowledge and abilities. ${ }^{6}$ National Endowment for Financial Education reported similar findings, pointing to the gap between millennials' confidence in their financial knowledge and their competence, with 69 percent rating themselves high in financial knowledge but 24 percent exhibiting basic financial literacy. ${ }^{7}$

Millennials are not the only population pursuing college degrees, nor are they alone in this gap between perceived and demonstrated financial knowledge. A 2016 report from FINRA Investor Education Foundation showed that, while 76 percent of U.S. respondents of all ages rated themselves high in financial knowledge, only 37 percent scored 4 or higher out of 5 on a financial knowledge evaluation. ${ }^{8}$ The need for increased financial knowledge and education that can be applied postgraduation is also evident from Project Information Literacy's research on the information-seeking behaviors of recent college graduates. The study identified two major personal life learning needs, both of which have ties to financial literacy: learning how to live on one's own and filling gaps in financial knowledge. ${ }^{9}$

Financial literacy was selected as the 2013-2014 presidential focus of the Association of College \& Research Libraries (ACRL) division of the American Library Association (ALA), drawing the attention of academic libraries and academic librarians to issues of college affordability and increasing student loan debt, and examples of universities providing financial literacy education, among other strategies, to address these problems. ${ }^{10}$ ACRL's initiative called on academic libraries as providers of reliable knowledge, trusted educators, and campus partners to consider their unique position and potential to address needs and fill gaps for financial literacy education. ${ }^{11}$ Likewise, ALA's Reference \& User Services Association (RUSA) promoted library involvement in financial literacy, developing the RUSA Financial Literacy Education in Libraries: Guidelines and Best Practices for Service in 2014 and forming the Financial Literacy Interest Group in 2016. The RUSA Financial Literacy Interest Group is "focused on sharing ideas and building a community around those already engaged in or interested in exploring the topic of financial literacy and libraries," and academic librarians comprise the majority of its membership. ${ }^{12}$ Although these activities, as well as the authors' experiences and case studies in the literature, suggest possible academic library interest and participation in student financial literacy, there has been limited research on academic library support for this topic. Through this study, the authors aim to explore the roles, opportunities, and challenges of academic library support for financial literacy.

\section{Background and Research Questions}

The authors have both been directly engaged in support for campus financial literacy at a large academic library. One has been involved as a librarian and the other as an undergraduate peer-to-peer financial educator from 2015 to 2017. In this article, the authors examine the status of financial literacy initiatives in academic libraries by surveying librarians at large institutions. The authors aim to address the following questions: 
- Are financial literacy topics perceived by librarians as important for college students?

- What are large academic libraries doing in support of financial literacy?

- What are the challenges and barriers faced by libraries interested in student financial literacy?

- What prompted library financial literacy initiatives?

- What opportunities might encourage or support library financial literacy initiatives?

This study is intended to fill a gap in the research by benchmarking library interest and involvement in student financial literacy and the types of support offered. The persistent media attention on the effects of student debt on home ownership, business startups, and the economy in general; and the individual financial struggles of those with student debt is often met with calls for universities to address these concerns through financial literacy education and other strategies. ${ }^{13}$ Academic libraries faced with decisions about if and how they can participate in these initiatives may find this study valuable in examining the opportunities and challenges of student financial literacy support. The results may also aid librarians interested in financial literacy in identifying the library personnel and outside partners involved in and responsible for student financial literacy, and anticipating potential challenges and opportunities.

\section{Literature Review}

Outside of library science, financial educators define financial literacy in numerous and different ways, but many definitions highlight both knowledge and application as part of financial literacy, similar to this definition developed by National Financial Educators Council: "possessing the skills and knowledge on financial matters to confidently take effective action that best fulfills an individual's personal, family and global community goals." In a methodical study of library science literature, Faulkner found that there is no agreed-upon definition for "financial literacy" in library science; the term is relatively new to libraries, first appearing in library science literature in 2002 and coinciding with media coverage and U.S. government interest in the topic. ${ }^{14}$ As libraries and librarians continued discussions about "financial literacy," the role of libraries has emerged as a topic of substantial interest and exploration. The role of academic librarians in particular is explored through case studies that provide varied examples of ways academic libraries have sought to address student financial education needs, offer financial information and knowledge for decision making and application, and become involved in financial literacy efforts on their campuses.

Among the examples are collections-related opportunities such as developing curated lists and guides to online financial literacy resources. Livengood and Venditti provide a selection of financial literacy resources and demonstrate how academic librarians can contribute to campus financial literacy by identifying and promoting authoritative sources for financial decision-making, education, and research. ${ }^{15}$ Faulkner also explored library collections for financial literacy in a study that evaluates popular personal finance literature. ${ }^{16}$ Faulkner further discovered overlaps and differences between this genre and financial literacy-related library programming. ${ }^{17}$ Programming, events, and workshops are another example of academic library participation in student financial literacy. For example, in 2017, more than 1,000 libraries, including academic, public, school, prison, and other types, participated in Money Smart Week @ your library, an initiative of ALA and the Federal Reserve Bank of Chicago that encourages libraries to provide financial literacy programming during a specified week in April. ${ }^{18}$ 
Collaboration with other campus entities is a theme in the literature on academic library involvement in financial literacy, with libraries commonly seeking out partners on campus or in the community that already provide financial education programming or offer other financial expertise. In a case study, Gil demonstrates an array of approaches to involvement in campus financial literacy, including programming, partnership, and committee leadership and service. ${ }^{19}$ Specifically, Gil established a Money Smart Week planning committee with members from across campus units, including representation from the College of Business, Career Center, Financial Aid office, and student government. Under Gil's leadership, the committee planned and delivered 11 programs, including topics such as library resources for financial literacy, student loans, credit and money management, startup financing, and investing. Jagman, Lewis, Nunn, and Walter discuss financial literacy as part of the curriculum and cocurriculum at their four-year university and highlight the library's participation in overarching partnerships with the first-year experience program, Financial Fitness Program, and Career Center that intersect with financial literacy. ${ }^{20}$

Academic librarians have also explored the relationship between financial and information literacy and aimed to integrate financial literacy into library instruction. In their chapter, Gass and Garczynski detail the creation of a workshop on investing sources in which students interact with investment information sources (10-Qs, analyst reports, company financials, business articles) and evaluate authorship, audience, purpose, biases, and connections with other sources. ${ }^{21}$ The authors designed the workshop to align with the "Information Has Value" and "Scholarship as a Conversation" frames of the ACRL Framework. Librarians have also connected financial literacy with career information literacy, which introduces students to reliable sources that guide their career paths and support informed financial decision-making as they near graduation. ${ }^{22}$ For example, Geraci, Hickey, and LaVoice demonstrated that librarians can provide students with guidance on career and salary data sources for salary negotiation and work in partnership with career centers. ${ }^{23}$ At a community college library, Roggenkamp has offered both course-related and non-course-related financial literacy instruction sessions on scholarships, alternative college financing strategies, and budgeting. ${ }^{24}$ Academic librarians have also served as instructors of credit courses on personal finance topics. For example, $\mathrm{Li}$ was the instructor of a one-credit course for first-year undergraduate students that integrated financial and information literacy. ${ }^{25}$

Academic librarians also participate in financial literacy support as part of reference and information services. Joe highlights financial aid questions and answers that reference librarians in an academic setting may encounter, and Kraus discusses inheritance, retirement, debt collection, philanthropy, bankruptcy, student loan, and scholarship reference questions from students in a series of case studies. ${ }^{26}$ Both Joe and Kraus acknowledge the legal and ethical concerns librarians may have when addressing financial-related questions and stress the library's role in directing students to key trusted resources and information. The literature also includes examples of academic libraries hosting peer-to-peer financial literacy programs. Reiter describes a peer-to-peer financial literacy program housed in the library at a large academic university, while Moody discusses the development of such a program at a small liberal arts college, demonstrating how this type of program has been employed at institutions of vastly different sizes. ${ }^{27}$

While the literature provides evidence of academic libraries' involvement in student financial literacy and numerous examples of how to incorporate financial literacy activities 
into practice through collections, programming, partnerships, information literacy instruction, and reference services, these efforts have not yet been captured systematically. Previous surveys have focused on the financial literacy activities, challenges, and opportunities of public libraries, ${ }^{28}$ or libraries in general, such as a survey by a working group of the RUSA division of $\mathrm{ALA},{ }^{29}$ but there have not been any surveys specifically targeting academic libraries or librarians. By surveying librarians at large academic institutions, this study fills a gap in the literature and examines academic libraries' interest in financial literacy and the related activities, barriers, partners, and possibilities.

\section{Methodology}

Since there has not yet been a systematic examination of financial literacy initiatives in academic libraries, the authors developed a survey questionnaire to collect and analyze quantitative and qualitative data from librarians at large universities to learn more about their experiences with student financial literacy. Taking an exploratory approach, the authors were interested in discovering whether or not libraries engaged in student financial literacy on university campuses, the types of support offered, and the personal finance topics of interest through closed survey questions, and identifying the barriers, challenges, and personnel involved through open survey questions.

\section{Survey Design}

The survey instrument (available in appendix) and protocol were reviewed by Penn State University's Institutional Review Board and determined to be exempt before distribution. The authors designed the branched survey instrument using Qualtrics. The survey consisted of nine questions, including multiple-choice and open-ended types.

The authors developed questions based on the topics noted in the literature, as well as their own experiences. Question 1 of the survey gauged awareness of and interest in specific financial topics for college students. Question 2 asked participants to indicate whether or not their library offers any types of support for financial literacy, including resource guides, programs, collection development, instruction, and collaborations across campus. The authors wanted to explore the reasons libraries did not participate in student financial literacy. Those who indicated "no" in question 2 were directed to a branch of the survey with one question (question 3) that asked about barriers to offering student financial literacy support before proceeding to the final question (question 9), which was asked of all respondents.

The authors also wanted to learn more about the efforts of those libraries that did provide financial literacy support, so those who answered "yes" to question 2 were directed to a branch that included five questions (questions 4-8) about the types of support offered, partners, challenges, the impetus for offering financial literacy support, and who or what department is leading the efforts. After these five questions, participants were directed to the final question. The final question (question 9) asked what forms of support would encourage participation in campus financial literacy so the authors could identify future directions for research and practice.

\section{Survey Population and Dissemination}

The authors compiled a master list of universities of more than 10,000 students from publicly available data. While libraries at universities and colleges of many sizes do participate in stu- 
dent financial literacy according to the literature in the field, the authors chose to focus the survey on librarians at large universities of 10,000+ students to enable a manageable survey population. Additionally, the authors' experiences with student financial literacy at a large university made this population of greatest familiarity and interest. The authors acknowledge the limitations of focusing this research solely on large academic institutions. The list of universities of 10,000+ students included representation from universities with Carnegie Classifications of Doctoral Universities (165), Master's Colleges and Universities (85), and Baccalaureate Colleges (6). Examples from library literature primarily emphasized financial literacy support for undergraduate students, and the majority of the student populations at these institutions were undergraduates, with the following enrollment profile Carnegie classifications: majority undergraduate (28), high undergraduate (152), and very high to exclusive undergraduate four-year (76).

To ensure that the survey received no more than one response from an individual university library, the authors opted to develop a targeted list of individuals to invite to participate. Based on library literature in the area of financial literacy, which includes numerous articles written by business librarians, the authors made the assumption that those with subject, liaison, or similar responsibilities for business, economics, finance, and related areas would be the most likely to be able to speak to library financial literacy activities. The authors reviewed staff lists, LibGuides and similar resource guides, and other content on the websites of academic libraries at the institutions on the master list and collected contact information for individuals who appeared to have subject responsibilities in business, economics, finance, and related areas.

The total number of individuals invited to participate in the survey was 256. In January 2017, the authors sent an email with the survey link to 256 individuals. The survey was open for a two-week period, with one reminder sent a week before the deadline. Of those surveyed, 72 responded before the deadline, resulting in a response rate of 28 percent. However, 7 respondents did not complete the survey; their responses were removed to provide a uniform set of data. The total number of responses analyzed was 65, resulting in an overall response rate of 25 percent. At a confidence level of 95 percent and a margin of error of approximately 10 percent, the survey results are suitable for an initial exploration into the financial literacy activities of academic libraries and can be considered to be indicators of the status of these initiatives.

\section{Results}

\section{Are financial literacy topics perceived by librarians as important for college students?}

To gauge the librarian interest and awareness of student financial literacy, all survey respondents were asked to identify personal finance topics that were perceived as important to students at their university (question 1). Percentages total more than 100 percent because respondents could select as many topics as they believed to be relevant. The most selected topics were personal finance basics $(97 \%, \mathrm{n}=63)$, student loans $(97 \%, \mathrm{n}=63)$, budgeting $(95 \%$, $\mathrm{n}=62)$, and credit cards $(91 \%, \mathrm{n}=62)$. Following these top four selections were saving $(77 \%$, $n=50)$, salary negotiation $(77 \%, n=50)$, health insurance $(74 \%, n=48)$, paying for rent or mortgage $(71 \%, \mathrm{n}=46)$, car loans $(68 \%, \mathrm{n}=44)$, investing $(58 \%, \mathrm{n}=38)$, retirement $(54 \%, \mathrm{n}=$ $35)$, other $(11 \%, n=7)$, and none $(2 \%, n=1)$. Other topics suggested by respondents included taxes; research skills to find quality financial literacy sources; cost of living; and scholarships. 
In follow-up to this question on important financial literacy topics, respondents were asked if their library actively participated in student financial literacy efforts. Of the 65 survey respondents, 52 percent $(\mathrm{n}=$ 34) indicated that their library was not involved in student financial literacy and 48 percent $(n=31)$ indicated that their library was involved in student financial literacy (question 2).

Those who indicated they did not participate in student financial literacy completed a question about what prevents their library from offering student financial literacy support (question 3). Respondents were given a list of potential barriers and could

\begin{tabular}{|l|c|c|}
\hline \multicolumn{3}{|c|}{ TABLE 1 } \\
Importance of Financial Literacy Topics \\
\hline \multicolumn{1}{|c|}{ Topic } & Frequency & Percentage \\
\hline Personal finance basics & 63 & $97 \%$ \\
\hline Student loans & 63 & $97 \%$ \\
\hline Budgeting & 62 & $95 \%$ \\
\hline Credit cards & 59 & $91 \%$ \\
\hline Saving & 50 & $77 \%$ \\
\hline Salary negotiation & 50 & $77 \%$ \\
\hline Health insurance & 48 & $74 \%$ \\
\hline Paying for rent or mortgage & 46 & $71 \%$ \\
\hline Car loans & 44 & $68 \%$ \\
\hline Investing & 38 & $58 \%$ \\
\hline Retirement & 35 & $54 \%$ \\
\hline Other & 7 & $11 \%$ \\
\hline None & 1 & $2 \%$ \\
\hline
\end{tabular}
select as many as applied, so percentages total more than 100 percent. Lack of time was identified by 74 percent of these respondents as a barrier to offering student financial literacy support $(n=25)$. Twenty-one percent reported that another reason they were not involved was that financial literacy was the responsibility of another campus unit/department $(n=7)$. They identified a variety of entities as responsible for supporting financial literacy on their campuses, including money management centers; offices of student affairs, financial aid, undergraduate education, and career development; and courses in personal financial planning and first-year experience. Additional reasons that the library did not participate in student financial literacy included lack of financial resources $(18 \%, n=6)$, lack of interest $(15 \%, n=5)$, lack of financial knowledge $(9 \%, n=3)$, university has a required student financial literacy program or course $(9 \%, n=3)$, lack of information resources $(3 \%, n=1)$, and other $(26 \%, n=9)$. Other reasons provided included not having enough staff to meet other library needs; lack of student interest in previous attempts to offer financial literacy support; that financial literacy is taught in high schools or by other university departments; and that financial literacy is outside the responsibilities of the library, which focus on course-related needs.

TABLE 2

What Prevents Library from Offering Financial Literacy Support?

\begin{tabular}{|l|c|c|}
\hline Reason & Frequency & Percentage \\
\hline Lack of time & 25 & $74 \%$ \\
\hline Other & 9 & $26 \%$ \\
\hline Responsibility of another department & 7 & $21 \%$ \\
\hline Lack of financial resources & 6 & $18 \%$ \\
\hline Lack of interest & 5 & $15 \%$ \\
\hline Lack of financial knowledge & 3 & $9 \%$ \\
\hline University has required program or course & 3 & $9 \%$ \\
\hline Lack of information resources & 1 & $3 \%$ \\
\hline
\end{tabular}




\section{What are large academic libraries doing in support of financial literacy?}

To learn more about the activities of those libraries that provided student financial literacy support, those who indicated "yes" in question 2 skipped question 3 and completed questions about what types of support their library offered, what partners (if any) they engaged, challenges faced, factors that influenced their involvement, and who in the library was leading the financial literacy efforts (questions 4-8). When asked what types of support their libraries provided (question 4), respondents indicated a wide range of activities, including financial literacy collection development $(55 \%, \mathrm{n}=17)$; collaboration with campus partners $(52 \%, \mathrm{n}=16)$; programming, events, and workshops $(45 \%, \mathrm{n}=14)$; online resource guides $(39 \%, \mathrm{n}=12)$; service

\begin{tabular}{|c|c|c|}
\hline \multicolumn{3}{|c|}{$\begin{array}{c}\text { TABLE } 3 \\
\text { Types of Financial Literacy Support Offered by } \\
\text { Academic Libraries }\end{array}$} \\
\hline Type & Frequency & Percentage \\
\hline Collection development & 17 & $55 \%$ \\
\hline Collaborations & 16 & $52 \%$ \\
\hline Programming, events, workshops & 14 & $45 \%$ \\
\hline Online resource guides & 12 & $39 \%$ \\
\hline University committee service & 4 & $13 \%$ \\
\hline Handouts & 3 & $10 \%$ \\
\hline $\begin{array}{l}\text { Integrated into information } \\
\text { literacy sessions }\end{array}$ & 3 & $10 \%$ \\
\hline Money Smart Week @ Your Library & 3 & $10 \%$ \\
\hline Other & 3 & $10 \%$ \\
\hline Personal finance courses & 1 & $3 \%$ \\
\hline Peer-to-peer programs & 0 & $0 \%$ \\
\hline
\end{tabular}
on campus financial literacy committees $(13 \%, n=4)$; participation in Money Smart Week $(10 \%, n=3)$; integration of financial literacy into library instruction $(10 \%, \mathrm{n}=3)$; handouts $(10 \%, \mathrm{n}=3)$; personal finance courses taught by library staff $(3 \%, \mathrm{n}=1)$; other $(10 \%, \mathrm{n}=3)$; and peer-to-peer financial literacy programs $(0 \%, \mathrm{n}=0)$. Percentages total more than 100 percent because respondents could select as many types of support as they offered. Other forms of support described by respondents include book displays, job search instruction, and one-on-one financial literacy coaching.

To find out more about financial literacy collaborations between academic libraries and others, respondents were asked what partners they engaged in their financial literacy activities, if any (question 5). Results showed the following partners: academic colleges $(n=17)$, financial aid offices $(n=10)$, career services $(n=8)$, first-year experience $(n=7)$, student affairs $(\mathrm{n}=4)$, financial literacy office $(\mathrm{n}=$

TABLE 4 Campus Partners

\begin{tabular}{|l|c|c|}
\hline Partner & Frequency & Percentage \\
\hline Academic college or department & 17 & $50 \%$ \\
\hline Financial aid & 10 & $29 \%$ \\
\hline Career services & 8 & $24 \%$ \\
\hline First-year experience & 7 & $21 \%$ \\
\hline No collaborators & 5 & $15 \%$ \\
\hline Student affairs & 4 & $12 \%$ \\
\hline Financial literacy/education office & 3 & $9 \%$ \\
\hline Bursar & 1 & $3 \%$ \\
\hline Other & 1 & $3 \%$ \\
\hline
\end{tabular}
$3)$, bursar $(n=1)$, and other partners such as campus credit unions $(\mathrm{n}=1)$. Academic college and department partners identified included colleges of business and interdisciplinary studies; departments and centers associated with personal finance, management, entrepreneurship, real estate, and economic development; and athletics. Five respondents indicated that they did not work with campus partners. 


\section{What are the challenges faced for libraries interested in student financial literacy?}

To gain a deeper understanding of libraries engaged in financial literacy activities, the survey asked open-ended questions about the challenges faced, the library's motivation for providing student financial literacy support, and who is involved in financial literacy efforts within the library (questions 6-8). The authors analyzed the open-ended questions qualitatively using an open coding process to find themes in the data. The responses to the question about challenges (question 6) were coded into the following thematic categories: lack of student interest $(n=10)$, lack of time $(n=7)$, difficulties with collaboration $(n=7)$, lack of money $(n=4)$, lack of financial knowledge $(n=3)$, and not applicable $(n=2)$. More than one code was applied to responses if applicable.

The most often cited challenge faced in offering support for student financial literacy was lack of time, similar to the primary barrier faced by those who do not participate in financial literacy activities. Some illustrative responses related to this challenge include the following:

- I'm the only business librarian in my library so if a financial literacy workshop or event happens I'm the one who has to coordinate it all.

- Our library offered a small series of financial literacy workshops three years ago and has not had the staff time to repeat the effort since then despite a desire to do so.

- We started doing individual instruction, but with our staffing it wasn't sustainable because it was REALLY popular and we had one librarian doing it.

Another challenge was lack of student interest as described in the following examples:

- Low attendance at events.

- Attendance is typically spotty [at workshops] and most students seem to be there only for the free food.

- Getting students to understand the importance of financial literacy.

Respondents also reported facing difficulties with identifying and maintaining relationships with collaborators:

- There are many units on our campus who have different stakes in financial literacy - it can be hard to identify a value add for library partnership/collaboration beyond resources and space.

- There isn't a coherent plan for financial literacy on our campus, so our typical strategy of partnering with a unit that "owns" a topic doesn't work here. Instead, we find opportunities as they arise.

- Financial literacy has recently changed departments, so building a new relationship hasn't been a priority due to other commitments.

Other respondents identified lack of money as a challenge:

- [...] The University Provost requested this type of program be offered. Unfortunately, after the libraries took on the initiative to move forward, we were not funded nor received any kind of support. In other words, they "did not put their money where their mouths were."

- Lack of money for purchasing resources and assisting in programming.

- Loss of revenue to obtain library materials due to massive budget cuts in higher education. Additionally, a few respondents pointed to the lack of financial knowledge among library staff as an issue faced when attempting to offer financial literacy activities in an academic library: 
- Building financial literacy skills among employees in order to have them teach/lead workshops.

- There are limited staff members with enough knowledge of the issue to participate [in workshops].

The remaining comments were categorized as not applicable because respondents reported that their financial literacy activities had just begun and were not ready to identify specific challenges.

\section{What prompted library financial literacy initiatives?}

The survey asked respondents what prompted their libraries to participate in student financial literacy (question 7) to explore the motivations for library involvement. These responses were analyzed and sorted into the following categories: external influence $(n=10)$, filling a gap or need $(n=8)$, library mission professional values $(n=6)$, and individual initiative $(n=$ 3). Responses were coded into multiple categories when appropriate.

Those who were identified as becoming involved in student financial literacy as a result of external influence were affected by faculty, colleges, and other financial literacy partners reaching out to the library for program support and neutral space, as well as requests and directives from students and university administration. Examples of responses include the following:

- One of the strategic initiatives of our university is to foster financially literate students.

- A mention from the provost.

- Students requested financial literacy support; business school was in favor.

Librarians also saw their library as filling a gap or need, and described serving as the hub for financial literacy, whether the library was providing the only financial literacy effort on campus or creating a point of connection between multiple campus units engaged in the topic. Responses that exemplify this motivation include the following:

- There was no clearly identifiable unit or department on campus providing this type of support. By connecting with departments who provide some level of financial literacyrelated support, the library was able to serve as a central clearinghouse of sorts.

- There was no financial literacy effort on campus, we became the campus effort.

- Awareness that many of our students are graduating with huge student loans, and need good advice on how to negotiate their way through the minefield of debt.

- Lack of programming which focused upon the issue.

Library mission and values also factored into the decision to participate in student financial literacy, with respondents pointing to the library as a point of access and teaching for all types of information and literacies, including financial. Examples of responses include the following:

- Our library supports instruction for and competence in multiple literacies. College students are at particular risk for poor decisions guided by a lack of understanding of personal finances and the library believes in being an access point for many types of information, not just academic research.

- The cost of college is unaffordable; we're a large land-grant institution, and we have an obligation to help the people of our state access education. It's a natural fit.

- It's an important area of information literacy that is often overlooked.

Others were also driven by individual initiative, possessing expertise or passion in the subject area that they wanted to share: 
- Individual decision of business librarian (regarding collecting personal finance materials and collaborating with various career offices on campus).

- I have a strong personal belief in teaching students this information and heard anecdotes that there was a need.

The survey also asked who or what department was leading the library's student financial literacy efforts (question 8). Responses were coded into the following categories: business librarian $(n=14)$, department within library $(n=5)$, business school $(n=5)$, library support staff $(n=1)$, and no one $(n=1)$. Business librarians were most commonly identified as leading the library's efforts, a result that may have been skewed since librarians specializing in business and economics were targeted for this survey.

\section{What opportunities might encourage or support library financial literacy initiatives?}

To explore possibilities to facilitate financial literacy support among academic libraries, the final question asked what resources would be helpful (question 9). All respondents were asked this question whether or not their library participated in financial literacy efforts, and they were able to select as many options as they wanted, resulting in percentages totaling more than 100 percent. Financial Literacy Program-in-a-box $(68 \%, n=44)$ was the top selection, with Patron financial literacy training for libraries $(32 \%, n=21)$ and Personal financial literacy training for library employees $(31 \%, n=20)$ as the second and third top selection. The remaining results were None $(20 \%, n=13)$ and Other $(8 \%, n=5)$. Other suggestions included financial literacy mentors, practical examples, online guides or videos, and financial literacy information focused on graduate students.

\begin{tabular}{|l|c|c|}
\hline \multicolumn{3}{|c|}{ TABLE 5 } \\
\hline \multicolumn{3}{|c|}{ Possibilities to Support Financial Literacy Initiatives } \\
\hline Resource Type & Frequency & Percentage \\
\hline Financial Literacy Program-in-a-box & 44 & $68 \%$ \\
\hline Patron financial literacy training for library employees & 21 & $32 \%$ \\
\hline Personal financial literacy training for library employees & 20 & $31 \%$ \\
\hline None & 13 & $20 \%$ \\
\hline Other & 5 & $8 \%$ \\
\hline
\end{tabular}

\section{Discussion}

Prior to conducting this survey, based on the literature and their own observations, the authors anticipated that the results would suggest interest and participation from academic libraries in the financial literacy of students. The roughly 50/50 split between academic libraries that have participated in financial literacy efforts and those that have not is similar to the findings of RUSA working group's survey of libraries of all types. ${ }^{30}$ While this result was expected, the authors thought that those not engaged in financial literacy would be less interested or aware of student financial needs and thus those respondents who were not engaged in financial literacy support would identify significantly fewer financial topics of importance to college students. On average, those who did not participate in financial literacy support identified 8.1 topics of importance, while those who did participate in financial literacy efforts indicated 9.3 topics of importance. While those who did not participate identified fewer topics than those 
who did participate, the difference is not as great as expected, suggesting that librarians view financial literacy as a continuing trend of importance for college students, even if their library cannot or does not want to participate directly. By further comparing the responses of those who participated and those who did not, the authors revealed trends in barriers faced and identified possible solutions and strategies to overcoming those barriers. Additionally, the results suggest the need for further research.

\section{Barriers}

The perceived barriers of those who do not participate in financial literacy support and the challenges faced by those who do participate align closely, with lack of time, lack of money, lack of interest, and lack of financial knowledge appearing in both sets of responses. Time is a limited resource; therefore, it is unsurprising that lack of time was the top challenge expected or faced by all respondents. Academic libraries and librarians have an array of primary responsibilities to the university and its users, and student financial literacy efforts understandably may not take priority given time constraints, despite some librarians identifying student financial literacy as part of library mission and professional values. Additionally, the responsibility of financial literacy support sometimes falls to another entity on campus according to the survey results, giving the academic library further reason to commit its limited time to other endeavors.

The challenge of lack of money or financial resources to support financial literacy relates to fluctuating state and federal funding for higher education and the library budget cuts that may coincide with these changes, affecting a library's ability to build collections, hire staff, and begin or continue special initiatives. ${ }^{31}$ Lack of interest is a difficulty at institutions large and small where students have their academic studies to attend to while also participating in extracurricular activities and student engagement opportunities. Students may also have work or family commitments. Attracting student attention to yet another important topic is understandably frustrating to those attempting financial literacy services and daunting to those who do not offer support. Another shared challenge was lack of financial knowledge, although this was noted less frequently than other problems in both sets of results.

An additional reason identified by those who do not participate was that financial literacy was the responsibility of another entity on campus. Among those who do engage in student financial literacy, there was evidence that the libraries can work collaboratively with the units that are taking a leadership role in financial literacy. In these collaborations, the survey results suggested that challenges can arise, particularly around identifying potential partners and maintaining relationships. While respondents did not elaborate on their specific difficulties with collaboration, commonly faced challenges when working with outside financial literacy partners include miscommunication and a lack of shared goals and vision. ${ }^{32}$

\section{Solutions and Strategies}

Though the survey identified wide-ranging challenges and barriers faced by academic libraries, the results also suggest possible solutions and strategies for providing financial literacy support. For example, the survey finding that collection development is the most frequently cited type of support provided by the academic library is worth considering in relationship to the barriers identified by those who do not provide financial literacy support, in particular the "lack of time" barrier that dominated the results to question 3 and responses to the open-ended 
question 6. Purchasing resources that focus on personal finance or financial education may fit more easily than other types of financial literacy support into the schedules and activities of academic librarians with collection development duties, particularly those surveyed who were identified for their focus or specialty on business and economics. Targeted collection of personal finance resources may be an opportunity for librarians to contribute to campus financial literacy initiatives without taking too much additional time or disrupting their existing workflows. However, this approach would also potentially require financial resources, another challenge, to adequately meet needs.

The survey also suggested another solution for the challenges presented by lack of time: program-in-a-box, which was the most popular choice among all survey respondents. Given that lack of time was seen as a barrier by those who do not offer financial literacy support and a challenge to those who do, a ready-made program does appear to be an appropriate form of assistance. A "program-in-a-box" featuring ready-made presentations, simplified explanations of common consumer financial products, marketing materials, and training and organization guides could reduce time, cost, and effort needed to launch a financial literacy program within an academic library. A possible model for such a program, though not designed specifically for academic libraries, is available from the National Endowment for Financial Education, which develops Financial Workshop Kits that are equipped with a PowerPoint presentation, a script, guides for hands-on activities, informational handouts, related resources, and frequently asked questions. ${ }^{33}$ Smart Investing @ your library, a partnership between ALA and the FINRA foundation, and the Consumer Financial Protection Bureau also provide programming resources aimed at libraries, particularly for public types..$^{34}$ Libraries, librarians, and other interested parties that pursue the development of a "financial literacy program-in-a-box" targeting academic libraries might also consider ways to address challenges particular to university context that were identified in this research, such as navigating relationships with campus collaborators, meeting the information literacy and lifelong learning goals of the library, and furthering the overall mission of the university.

Collaborations, which were a type of support offered by 52 percent of respondents active in financial literacy, present an opportunity to overcome different barriers. For their partnerships and collaborations, academic librarians identified a wide variety of campus partners and notably identified partners that bring financial knowledge, such as the academic colleges, financial aid offices, financial literacy offices, bursar offices, and credit unions. Bringing in partners with financial expertise is a strategy for evading the "lack of financial knowledge" challenge noted by both those that do provide financial literacy support and those that do not. Career services, first-year experience, and student affairs bring a different value to the partnership: the opportunity to reach students at critical points of their college career that may intersect with financial questions, whether it is when they are preparing for graduation, getting started at the university, or dealing with a difficult issue. This may help address the "lack of interest" barrier by meeting students at a point of need.

\section{Opportunities for Further Research}

The library may be competing for students' time and attention with the many other opportunities that college provides, including other campus departments that provide financial literacy support, which are emerging at large academic institutions under names such as money management centers, financial literacy offices, and wellness centers. ${ }^{35}$ If students receive financial 
literacy support from other campus groups, what roles and opportunities remain available to libraries? Further research is needed to explore the unique roles and opportunities. It is possible that merely the presence of a financial literacy program on a college campus may inspire more students to think about their finances and conduct personal research into how to improve their circumstances.

Entities beyond the university are also interested in targeting financial literacy programming resources toward the college student audience, including financial institutions and nonprofit organizations. By investigating the motivations of libraries to participate in financial literacy activities, the authors inadvertently uncovered an example of how libraries may be able to uniquely contribute to these efforts: by supporting financial literacy as part of information literacy. Although this topic has been discussed conceptually and in case studies in library literature, ${ }^{36}$ further studies on the intersection of financial literacy and information literacy could help answer remaining questions, such as whether or not college students seek out financial education from commercial, government, nonprofit, or other sources on their own, how they determine the validity of the information they find, and how they apply the knowledge gained to their decision-making. Future research on these questions could provide clarity and guidance on the role for librarians in helping students untangle the wide, and sometimes conflicting and confusing, web of financial answers available on the internet. Other roles for librarians, as well as evidence on the level of library activity in specific types of financial literacy support, such as hosting programs or maintaining resource guides, could be explored via content analysis of library websites.

While most of the types of support found in the literature appeared in the survey results, peer-to-peer financial literacy programs were absent. A possible explanation is that the large universities that were surveyed may have the resources to support campuswide offices or departments devoted to such specialized programs, so library support is not needed. One of the peer-to-peer financial literacy programs noted in the literature is located at Ripon College, which is a small liberal arts college; it was not included in the study sample. (The other program mentioned in the literature review was located at the authors' institution, but the authors did not participate in the study.) Exploring whether or not small- and mid-sized four-year colleges and universities, as well as community colleges, have devoted financial literacy programs, and if and how the academic libraries may be filling any financial education, information, or service gaps, is a topic worthy of investigation in future research.

\section{Conclusion}

This survey of the current state of financial literacy education at academic libraries at large institutions shows that, following the groundswell of attention due to the ACRL presidential focus of 2013-2014, there remains awareness of this topic among academic librarians as of 2017-2018. Survey respondents, whether or not their library provided financial literacy support, perceived personal finance topics as important to college students. Roughly half of the librarians surveyed reported involvement in student financial literacy efforts, and half did not participate, primarily due to lack of time. Time constraint was a challenge shared by those who did provide financial literacy programming. Of the proposed solutions that might make financial literacy education easier for libraries to offer, the "program-in-a-box" emerged as the possibility of greatest interest to respondents and would offer the potential time savings that librarians seek. By analyzing and drawing comparisons from survey results, the authors 
also identified collaboration as a strategy to mitigate many of the challenges, including lack of financial knowledge and low student interest, and targeted development of personal finance collections as an opportunity for academic libraries to make a unique contribution to student financial literacy support with limited disruption to the existing workflows and responsibilities.

This study explores the status of financial literacy efforts of academic libraries at large academic institutions and recognizes the interests, challenges, and examples of initiatives that may be shared by academic librarians at institutions of all types and sizes. Although not all academic libraries surveyed are involved in financial literacy support, it is not unreasonable to expect that they may face the external influence or professional motivation that prompted others to participate according to the qualitative data collected, given the ongoing media coverage of financial literacy, college affordability, student debt, and the value of higher education. While it is beyond the scope of this exploratory study to suggest what academic libraries should do given the unique challenges at each institution, this study provides evidence that, despite the challenges, academic libraries can participate in financial literacy support for students and are doing so with university and library values in mind. 


\section{APPENDIX}

\section{Survey Instrument}

You are invited to participate in an online survey on the role of academic libraries in student financial literacy. This survey is being conducted by Lauren Reiter, a Penn State University librarian, and Bronson Ford, a Penn State University student. This survey should take approximately 5 minutes to complete.

This survey is being conducted for research purposes and has met the criteria of the Institutional Review Board at Penn State University. Your participation in this survey is completely voluntary. Your responses will remain confidential. No personally identifiable information is being collected in this survey. You may skip questions, choose not to answer questions, and exit the survey without completing it at any time.

If you have any questions about this research, you can contact Lauren Reiter by phone at 814-865-4414 or email lmr29@psu.edu. Thank you for your time and attention.

By selecting to begin the survey below, you acknowledge that your participation in the study is voluntary, you are at least 18 years of age, and that you are aware that you may choose to terminate your participation in the study at any time and for any reason.

1. I consent. Begin the survey.

2. I do not consent. I do not wish to participate.

\section{Q1. Please check off any of the following financial literacy topics that you} believe are important for students at your university.

$\square$ Personal finance basics

$\square \quad$ Budgeting

- Credit cards

$\square$ Student loans

- Car loans

Paying for rent or mortgage

$\square$ Retirement

$\square$ Saving

$\square$ Investing

- Salary negotiation

- Health insurance

$\square$ Other (Please describe below)

$\square$ None

Q2. Does your library offer any type of support for student financial literacy (ex. resource guide, programs and events, instruction, promotion of personal finance book collection, collaborations with other campus units, etc.)?

$\begin{array}{ll}\square & \text { Yes } \\ \square \quad \text { No }\end{array}$

(If yes, skip to Q4.) 
Q3. What prevents your library from offering student financial literacy support? Check all that apply.

$\square$ Lack of interest

․ Lack of time

Lack of financial knowledge

- Lack of financial resources

$\square$ Lack of information resources

$\square$ University already offers a required financial literacy program or course for students

- Student financial literacy support is the responsibility of another unit/department at my campus. Please identify entity below (example: Financial Wellness Center, Office of Financial Aid, etc.)

$\square$ Other (please describe or expand on previous answers)

(Skip to Q9)

Q4. What types of support does your library offer for student financial literacy? Check all that apply.

口 Programming, events, workshops

$\square \quad$ Online personal finance resource guides

$\square$ Brochures, flyers, and other print handouts in the library

$\square$ Collection development focused on financial literacy and personal finance resources

$\square \quad$ Credit and noncredit personal finance courses taught by library staff

$\square \quad$ Financial literacy integrated into information literacy sessions

$\square \quad$ Peer-to-peer financial literacy programs

$\square$ Collaborations with other campus units

$\square$ Library staff service on university and campus committees related to financial literacy

- Participation in Money Smart Week @ Your Library (a national initiative between the ALA and the Federal Reserve Bank Chicago to provide financial literacy programming)

$\square$ Other (Describe below)

Q5. Identify any entities your library has collaborated or partnered with to offer any type of student financial literacy support. Please check all that apply.

Financial aid

Bursar

Career services

$\square$ Financial literacy/education office

$\square \quad$ First-year experience

$\square$ Student affairs

․ Academic college or department (Please describe below)

$\square \quad$ Other (Please describe below)

$\square$ My library has not collaborated or partnered to offer any type of student financial literacy support. 


\title{
Q6. What challenges has your library faced in providing support for student financial literacy?
}

\author{
Q7. What factors contributed to your library's decision to support student \\ financial literacy?
}

\section{Q8. Who/what department is leading your library's student financial literacy efforts?}

\section{Q9. Please check off any of the following that would be of interest to your library.}

口 Patron financial literacy training for library employees

- Personal financial literacy training for library employees

Financial Literacy Program-in-a-box (ready-made presentations, marketing, etc.)

$\square \quad$ Other (please describe)

$\square$ None

\section{Notes}

1. Board of Governors of the Federal Reserve System, "Report on the Economic Well-Being of U.S. Households in 2014" (May 2015), available online at https://www.federalreserve.gov/econresdata/2015-economic-wellbeing-of-us-households-in-2014-preface.htm [accessed 3 April 2018]; Board of Governors of the Federal Reserve System, "Report on the Economic Well-Being of U.S. Households in 2015" (May 2016), available online at https:// www.federalreserve.gov/econresdata/2016-economic-well-being-of-us-households-in-2015-preface.htm [accessed 3 April 2018]; Board of Governors of the Federal Reserve System, "Report on the Economic Well-Being of U.S. Households in 2016," Board of Governors of the Federal Reserve System (May 2017), available online at https://www. federalreserve.gov/publications/2017-economic-well-being-of-us-households-in-2016-preface.htm [accessed 3 April 2018].

2. Institute for College Access \& Success, "Student Debt and the Class of 2016" (Sept. 2017), available online at https://ticas.org/content/pub/student-debt-and-class-2016 [accessed 30 March 2018].

3. "CFPB Finds Percentage of Borrowers with $\$ 20 \mathrm{~K}$ in Student Debt Doubled Over Last Decade," Consumer Financial Protection Bureau, available online at https://www.consumerfinance.gov/about-us/newsroom/cfpb-findspercentage-borrowers-20k-student-debt-doubled-over-last-decade/ [accessed 3 April 2018].

4. The Ohio State University, "Study on Collegiate Financial Wellness: 2017 Key Findings Report" (2017), available online at https://cssl.osu.edu/posts/documents/2017-scfw-key-findings-report.pdf [accessed 3 April 2018].

5. PwC, "Millennials \& Financial Literacy: The Struggle with Personal Finance" (2015), available online at https://www.pwc.com/us/en/about-us/corporate-responsibility/assets/pwc-millennials-and-financial-literacy.pdf [accessed 30 March 2018].

6. Annamaria Lusardi and Noemi Oggero, "Millennials and Financial Literacy: A Global Perspective" (Global Financial Literacy Excellence Center, May 2017), available online at http://gflec.org/wp-content/uploads/2017/07/ Millennials-and-Financial-Literacy-Research-Paper.pdf?x87657 [accessed 20 March 2018].

7. National Endowment for Financial Education, "Millennials Gap Between Financial Confidence and Knowlege I NEFE," available online at https://www.nefe.org/Press-Room/News/Millennials-Gap-BetweenConfidence-and-Knowledge [accessed 3 April 2018].

8. FINRA Investor Education Foundation, "Financial Capability in the United States 2016," available online at www.usfinancialcapability.org/downloads/NFCS_2015_Report_Natl_Findings.pdf [accessed 5 June 2018].

9. Alison J. Head, "Staying Smart: How Today's Graduates Continue to Learn Once They Complete College" (Project Information Literacy, Jan. 5, 2016), available online at www.projectinfolit.org/uploads/2/7/5/4/27541717/ staying_smart_pil_1_5_2016b_fullreport.pdf [accessed 6 March 2018].

10. Trevor A. Dawes, "Libraries, ACRL and Financial Literacy: Helping Students Make Sound Decisions," College E Research Libraries News 74, no. 9 (Oct. 2013): 466-67; Trevor A. Dawes, "Academic Libraries' Impact on 
Financial Education: A Year of Programs and Projects," College \& Research Libraries News 75, no. 6 (June 2014): 326-27; David L. Eisler and Scott Garrison, "Addressing College Student Loan Debt: Strategies for Success," College E Research Libraries News 75, no. 7 (2014): 374.

11. Adi Redzic, "Financial Literacy," College \& Research Libraries News 74, no. 11 (Dec. 2013): 556-57.

12. Reference \& User Services Association, "Interest Groups," Reference \& User Services Association (RUSA), (Nov. 10, 2016), available online at www.ala.org/rusa/contact/interest-groups [accessed 20 June 2018]; "RUSA Interest Group: Financial Literacy Members," ALA Connect, available online at https://connect.ala.org/rusa/communities/community-home/community-members?communitykey=307cebd5-715a-4f4f-9880-7b669e679b36\&tab $=$ communitymembersdashboard\&Execute $=1$ [accessed 27 June 2018].

13. Dan Bauman, "Is Student Debt Big Enough to Hold Back the Economy? What the Research Says," Chronicle of Higher Education 65, no. 26 (Mar. 9, 2018): 46; Chris Quintana, "I 'Crushed' My Student Loans in Record Time. (Free Rent Helped)," Chronicle of Higher Education 64, no. 19 (Jan. 19, 2018): 1; Eisler and Garrison, "Addressing College Student Loan Debt: Strategies for Success."

14. Ashley E. Faulkner, "A Systematic Review of Financial Literacy as a Termed Concept: More Questions Than Answers," Journal of Business \& Finance Librarianship 20, no. 1-2 (Apr. 3, 2015): 7-26, https://doi.org/10.1080/ 08963568.2015.982446.

15. Stephanie P. Livengood and Kathryn L. Venditti, "Financial Literacy: A Primer for Librarians, Educators, and Researchers," College E Research Libraries News 73, no. 2 (Feb. 2012): 88-91.

16. Ashley E. Faulkner, "Financial Literacy Education in the United States: Exploring Popular Personal Finance Literature," Journal of Librarianship and Information Science 49, no. 3 (Nov. 20, 2015): 287-98, https://doi. org/10.1177/0961000615616106.

17. Ashley E. Faulkner, "Financial Literacy Education in the United States: Library Programming versus Popular Personal Finance Literature," Reference \& User Services Quarterly 56, no. 2 (2016): 116-25.

18. American Library Association, "Money Smart Week," American Library Association, available online at www.ala.org/aboutala/offices/money-smart-week [accessed 6 March 2018].

19. Esther L. Gil, "Leading the Way for Financial Literacy Education: A Case Study on Collaboration," Journal of Business \& Finance Librarianship 20, no. 1-2 (April 3, 2015): 27-53, https://doi.org/10.1080/08963568.2015.978710.

20. Heather Jagman et al., "Financial Literacy across the Curriculum (and Beyond).," College \& Research Libraries News 75, no. 5 (May 2014): 254-57.

21. Shana Gass and Joyce Garczynski, "Information Has Value: Financial Literacy Meets Information Literacy," in The Library's Role in Supporting Financial Literacy for Patrons (Lanham, MD: Rowman \& Littlefield, 2016), 53-62.

22. Frans Albarillo, "Teaching Career Information Literacy," in The Library's Role in Supporting Financial Literacy for Patrons (Lanham, MD: Rowman \& Littlefield, 2016), 189-98.

23. Aliqae Geraci, Daniel Hickey, and Kelly LaVoice, "Getting the Patron to Yes: The Academic Librarian's Role in Supporting Salary Negotiations," in The Library's Role in Supporting Financial Literacy for Patrons (Lanham, MD: Rowman \& Littlefield, 2016), 247-58.

24. John Roggenkamp, "Financial Literacy and Community Colleges," College \& Research Libraries News 75, no. 3 (Mar. 2014): 142-43.

25. Judy Li, "Serving as an Educator: A Southern Case in Embedded Librarianship," Journal of Business $\mathcal{E}$ Finance Librarianship 17, no. 2 (Apr. 1, 2012): 133-52, https://doi.org/10.1080/08963568.2012.661198.

26. Jennifer Wright Joe, "Quick Tip Guides on Student Financial Aid," in The Library's Role in Supporting Financial Literacy for Patrons (Lanham, MD: Rowman \& Littlefield, 2016), 199-206; Peter L. Kraus, "Giving Guidance When You Don't Have the Resources of a Swiss Bank: Answering Everyday Questions That Deal with Financial Literacy," Community \& Junior College Libraries 21, no. 1-2 (Apr. 3, 2015): 19-26, https://doi.org/10.1080/02763915.2015.1111094.

27. Lauren Reiter, "Financial Literacy and the Academic Library: Exploring the Peer-to-Peer Approach," Journal of Business \& Finance Librarianship 20 no. 1-2 (April 3, 2015): 54-65, https://doi.org/10.1080/08963568.2015.977 732; Kate Moody, "Money Fitness: One Academic Library's Experience of Building a Financial Literacy Program at a Small Liberal Arts College," in The Library's Role in Supporting Financial Literacy for Patrons (Lanham, MD: Rowman \& Littlefield, 2016), 275-84.

28. Catherine Arnott Smith and Kristin Eschenfelder, "Public Libraries in an Age of Financial Complexity: Toward Enhancing Community Financial Literacy," Library Quarterly 83, no. 4 (Oct. 2013): 299-320.

29. Kit Keller et al., "Meeting the Need for Library-Based Financial Literacy Education," Reference E User Services Quarterly 54, no. 3 (2015): 47-51.

30. Keller et al., "Meeting the Need for Library-Based Financial Literacy Education."

31. ACRL Research Planning and Review Committee, "Environmental Scan 2017" (Mar. 2017), available online at www.ala.org/acrl/sites/ala.org.acrl/files/content/publications/whitepapers/EnvironmentalScan2017.pdf [accessed 5 April 2018]. 
32. Kate Moody, "Asking for Help: Finding Partners for Your Financial Classes," in The Library's Role in Supporting Financial Literacy for Patrons (Lantham, MD: Rowman \& Littlefield, 2016), 121-30.

33. National Endowment on Financial Education, "Financial Education Tools \& Resources I Financial Workshop Kits," available online at https://www.financialworkshopkits.org/ [accessed 6 March 2018].

34. American Library Association, "Smart Investing @ Your Library I Financial and Investor Education Resources," available online at https://smartinvesting.ala.org/ [accessed 27 June 2018]; Consumer Financial Protection Bureau, "Financial Education Resources for Libraries," Consumer Financial Protection Bureau, available online at https://www.consumerfinance.gov/practitioner-resources/library-resources/ [accessed 27 June 2018].

35. University of North Texas, "Student Money Management Center I Division of Student Affairs," available online at http://studentaffairs.unt.edu/student-money-management-center [accessed 5 April 2018]; Syracuse University, "Financial Literacy I Syracuse University Office of Financial Literacy," available online at http:// financialaid.syr.edu/financialliteracy/ [accessed 5 April 2018]; Ohio State University, "Financial Education and Coaching : Student Wellness Center," available online at https://swc.osu.edu/services/financial-education-andcoaching/ [accessed 5 April 2018].

36. Li, "Serving as an Educator: A Southern Case in Embedded Librarianship"; Sonja Špiranec, Mihaela Banek Zorica, and Gordana Stokić Simončić, "Libraries and Financial Literacy: Perspectives From Emerging Markets," Journal of Business \& Finance Librarianship 17, no. 3 (June 27, 2012): 262-78, https://doi.org/10.1080/0896 3568.2012.686438; Faulkner, "A Systematic Review of Financial Literacy as a Termed Concept: More Questions Than Answers"; Gass and Garczynski, "Information Has Value: Financial Literacy Meets Information Literacy." 